\title{
Vermaan of bemoedig Johannes die kerke?!
}

$\mathrm{H}$ Theunissen

(UP)

\section{ABSTRACT}

\section{Does John exhort or encourage the churches?}

For many centuries Revelation has been the object of a mainly historical approach, legating us with a certain reconstructed historical situation as frame of reference: The church has been the object of persecution and the purpose of Revelation was to encourage the church.

This paper supports the contestation of the "traditional scenario" by concluding that the church lost its group-identity because boundaries between her and society were vague. John's intention is to cause the necessary alterations. He thus exhorts the church by means of warning, calls to repent and even threats.

This conclusion is the result of a symbolic-interactionistic analysis of Revelation that focuses on the construction of situations through symbols, the interaction between symbols and the grouping of symbols. The analysis and the corresponding actionlines make certain conclusions concerning the author's intention (the writing being a reflection of his minding-process) possible.

\section{Inleidende opmerkings}

Openbaring is die laaste paar eeue hoofsaaklik vanuit 'n historiese hoek benader met 'n "matige konsiderasie" van ander benaderings". Die erflating van hierdie verskynsel was enersyds dat die boek teen die agtergrond van 'n bepaalde gerekonstrueerde historiese situasie, naamlik vervolging verstaan is. Die geadresseerdes sou volgens hierdie "tradisionele scenario" in 'n tyd van groot verdrukking geleef het ${ }^{3}$. Andersyds is die oogmerk van Openbaring gesien as die aanspreek van hierdie verdrukkingskrisis. Openbaring is dus geskryf om die kerk te bemoedig4. Die laaste paar jaar word almeer besef dat die tradisionele scenario gebreke vertoon ${ }^{5}$. Die vraag aangaande die oogmerk van Openbaring verdien dus om weer aandag te kry. In hierdie verband is dit ter sake dat nuwe antwoorde nie soseer die gevolg is van meer data nie, maar van nuwe vrae, teorieë en voorveronderstellings ${ }^{6}$.

In die vermelde proefskrif is beredeneer dat die oogmerk van Openbaring in relasie met die intensie van die outeur staan' ${ }^{7}$ Genoemde 
intensie verskaf die verwysingsraamwerk vir die verstaan van die boek. Simboliese interaksionisme, 'n sosiaal-sielkundige perspektief, is aangewend om met hierdie oefening behulpsaam te wees ${ }^{8}$. Die simboliesinteraksionistiese konsep "situasie-defmisie" is as 'n analitiese perspektief gebruik.

\section{SITUASIE-DEFINISIE: 'N KORT ORIËNTERING}

Die konsep "situasie-defmisie" is van W I Thomas afkomstig wat meen: "Preliminary to any self-determined act of behaviour there is always a stage of examination and deliberation which we may call the definition of the situation" 9 . Hierdie definisie berus op bepaalde postulate ${ }^{10}$.

Eerstens vind interaksie nie situasieloos plaas nie ${ }^{1 !}$. 'n Akteur betree dus 'n bepaalde interseksie tussen tyd en ruimt, indikeer alle objekte in hirdie interseksie wat volgens hom ter sake is, heg betekenis aan sodanige objekte en orden of groepeer dan hierdie simbole ${ }^{12}$. Hierdie gekonstrueerde situasie (situasie-defmisie) verteenwoordig die situasie waarvolgens hy optree. Aksielyne word dus in die lig van die persepsie of siening wat die akteur het, bepaal.

Tweedens kan die simboliese waardes van objekte van die verwysingsgroep en deur middel van sosialiseringsprosesse verkry word ${ }^{13}$, maar dit hoef nie. Die simboliese kapasiteit van akteurs veroorsaak dat hulle voluntaristies optree. Die interaksieproses bepaal dus simboliese waardes.

Derdens word die Self geforseer om sy situasie-defmisie so aan te bied dat die groep met dieselfde persepsie of interpretasie werk sodat hulle sy aksielyne sal volg. Ten gronde van die voorafgaande proses lê die verskynsel van probleemoplossing.

Die analitiese perspektief waarmee Openbaring as teks ondersoek is ${ }^{14}$, behels dat situasies afgebaken is en die Self wat in die skrywe funksioneer, geïdentifiseer is. Afgebakende situasies is ontleed deur te let op watter objekte geïndikeer word en die simboliese waardes van hierdie objekte vas te stel. Daarna is gelet op die groepering van hierdie simbole, veral rondom akteurs. Daar is ook gelet op watter akteurs in interaksie met mekaar geskets word, asook die aard van en die rede vir die interaksie. Hierna is gelet op die aksielyne en of dit korreleer met die voorgestelde situasie-definisies. Gevolglik kon 'n konklusie gemaak word aangaande die probleem waarmee die Self worstel en dus die intensie van die outeur met die skrywe.

Die metodiese tegniek het behels dat die vrae wat situasie-defmisie aan die teks wil vra, asook die wyse waarop genoemde dit wil vra, versoen 
is met 'n semantiese lees van die teks. 'n Geïntegreerde tegniek is dus gebruik's.

\section{SITUASIE B (1:9-3:22): SITUASIE-DEFINISIE ${ }^{16}$}

'n Analise van 1:9-3:22 toon aan dat die primêre simbole in Situasie B, sowel as die aard van die eksplisiete interaksie tussen die simbole, soos volg saamgevat en diagrammaties voorgestel kan word ${ }^{17}$ :

\section{Figuur 1}

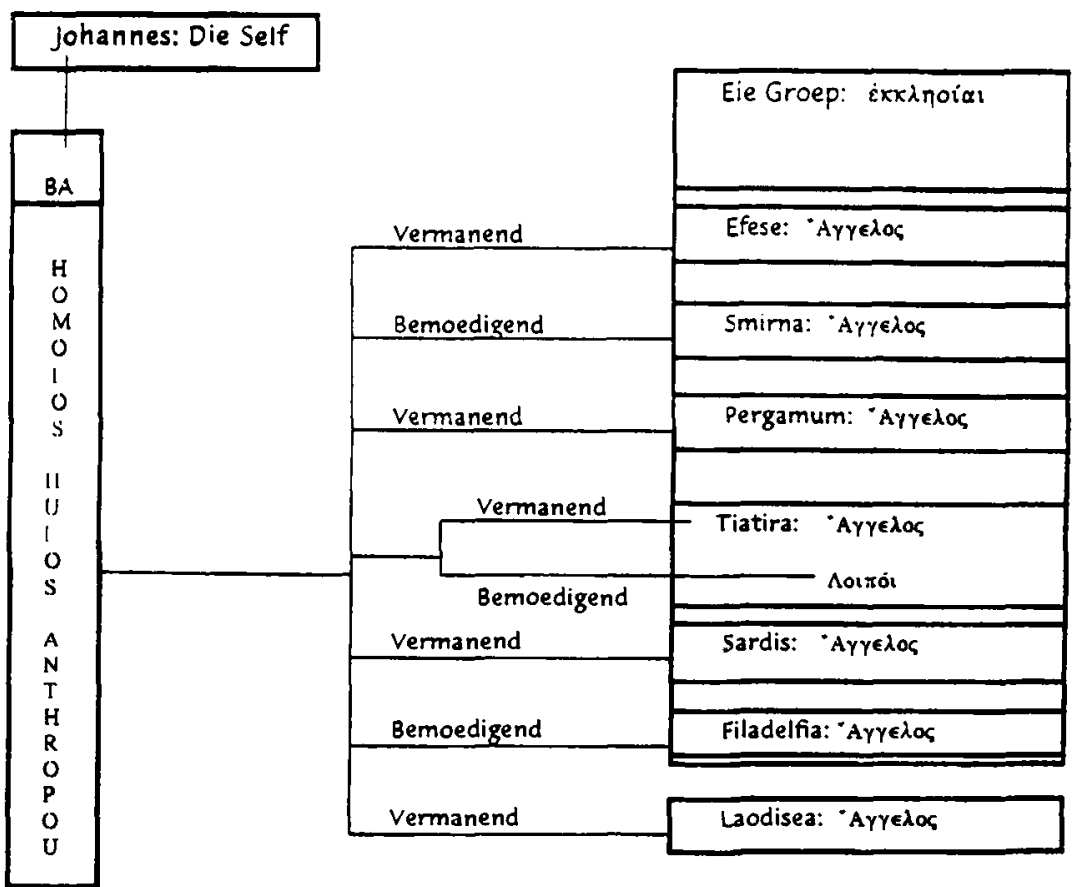

Die ordening van simbole in Situasie B, sover dit implisiete interaksie in die onderskeie kerke aangaan, sowel as teenpartye buite die kerk en implisiete interaksie met hierdie partye, kan soos volg saamgevat en diagrammaties voorgestel word: 
Figuur 2

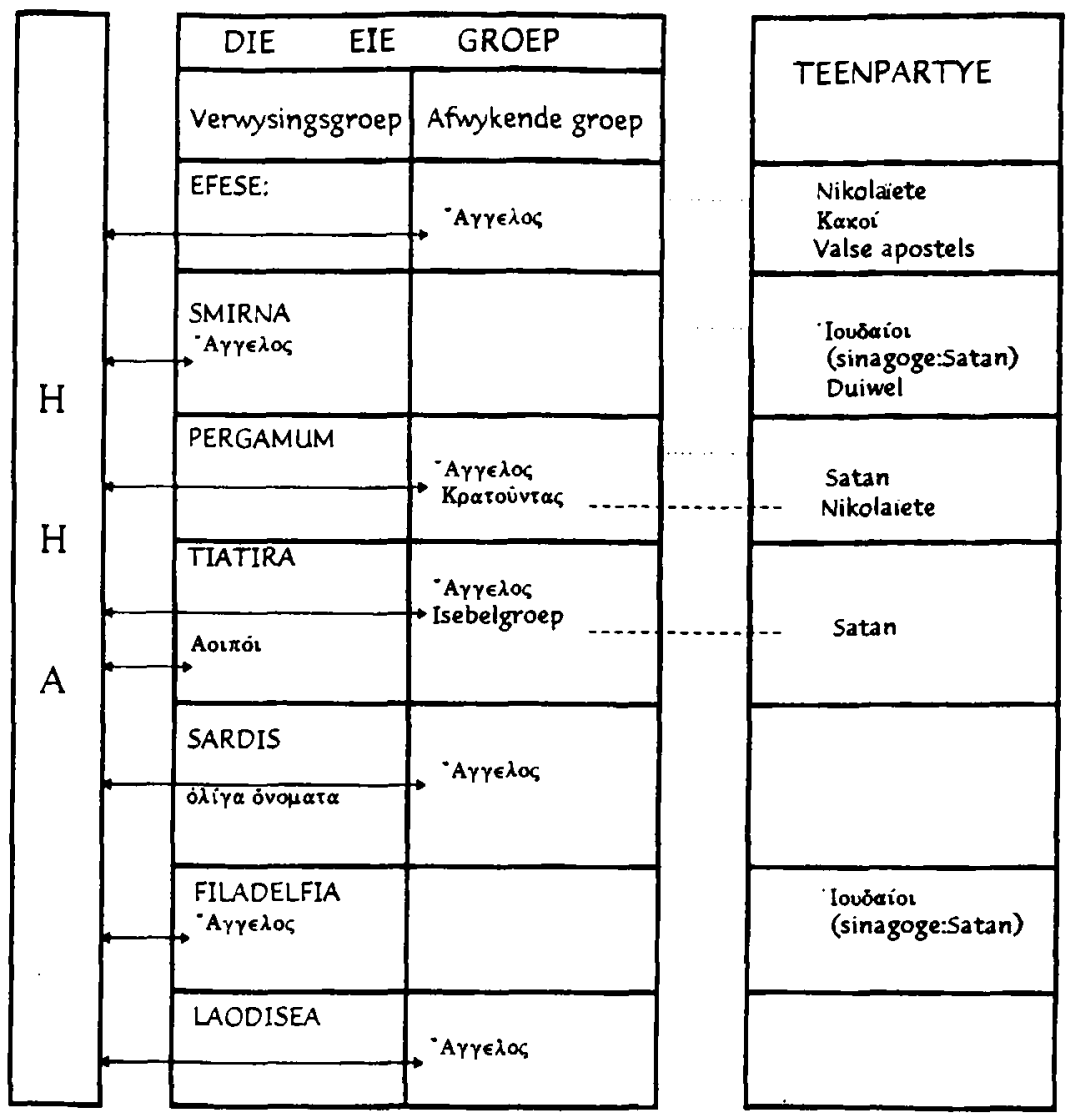

\subsection{Opmerkings aangaande Situasie B18}

* Akteurs: Die inleidende situasie (1:9-20) indikeer vier akteurs as ter sake in Situasie $\mathrm{B}^{19}$. HHA (homoios huios anthropou) word in interaksie geteken met Johannes. Die interaksie handel oor die gee van 'n opdrag deur HHA aan Johannes. Johannes moet dit wat hy sien, skryf aan die sewe kerkesituasies. B2-8 word vermeld wat Johannes aan elke kerk moet skryf.

In die beskrywing van laasgenoemde Situasies, is twee verskynsels belangrik. “A ${ }^{\prime} \gamma \varepsilon \lambda \circ \varsigma$, nie die kerke nie, word aangespreek ${ }^{20}$. Tweedens is 
HHA direk in interaksie met elke betrokke " $\alpha \gamma \gamma \varepsilon \lambda$ os en nie Johannes nie. SI (simbolies-interaksionisties) gesproke gebeur dus die omgekeerde van dit wat die teks oënskynlik aandui, naamlik HHA betree nie die situasies in die kerke by monde van Johannes nie, maar Johannes betree die situasies in die kerke by monde van HHA. SI gestel: die Self betree die situasies in die kerke aan die hand van sy BA $^{21}$.

* Interaksie: Die interaksie in situasies B2-8 (Figuur 1) geskied uitsluitlik tussen die BA (HHA) en die eie groep (kerk). Geen interaksie vind dus plaas tussen HHA en teenpartye nie ${ }^{22}$. Die eie groep word verteenwoordig deur $\alpha \gamma \gamma \varepsilon \lambda o s$. Die eie groep is gewoonlik ook die verwysingsgroep, dit wil sê die verteenwoordigers van die normes en waardes van die Self. Daar is egter gevalle waar die totale eie groep afwykend ten opsigte van genoemde normes en waardes funksioneer. In so 'n geval is die eie groep en die verwysingsgroep uiteraard nie identies nie. In ander gevalle is die eie groep nie die verwysingsgroep nie, maar 'n oorblyfsel in die midde van die eie groep vorm of verteenwoordig die verwysingsgroep.

* Die rede vir interaksie: Die interaksie in situasies B2-8 geskied op grond van drie kategorieë van probleme. In die geval van Efese, Sardis en Laodisea handel die interaksie oor probleme insake die verhouding met HHA. In die geval van Pergamum en Tiatira handel die interaksie oor probleme insake dwaalleer, sowel as die toelating van die dwaalleer of dwaalleraars in die kerk. In beide hierdie kerke handel die dwaalleer oor afgodsoffers en onsedelikheid. In die geval van Smirna en Filadelfia handel die interaksie oor geantisipeerde beproewing en die probleme wat dit vir die kerk mag inhou.

Die beskrywings van die kerk-situasies gee ook 'n aanduiding van eksplisiete en implisiete faktore wat aanleiding gee tot die probleme wat gedefinieer word. In hierdie verband word vier rolspelers geïdentifiseer. Die verhoudingsprobleem (Efese, Sardis en Laodisea) word deur die kerk self veroorsaak. Die eie groep is dus 'n rolspeler in sy eie probleme. Die dwaalleerprobleem (Pergamum en Tiatira) word veroorsaak deur afwyken-

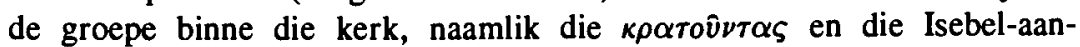
hangers. Daar is 'n verbintenis tussen hierdie afwykende groepe en die Nikolaïete. Die geantisipeerde lydingsprobleem (Smirna en Filadelfia)

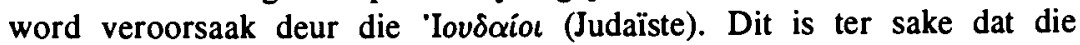
rolspelers by laasgenoemde twee probleme in verband met die Satan (duiwel) gebring word. Hierdie rolspelers funksioneer as deel van die Satansparty.

* Die intensie van die outeur: Die intensie van die outeur hou verband met bogenoemde probleme. Johannes sien sekere probleme in die 
kerke raak. Hy spreek hierdie probleemsituasies aan deur bepaalde aksielyne aan die kerke voor te skryf. Die aksielyne korreleer met die probleem-situasies en bevestig dus die opmerking insake intensie. Waar relasionele en dwaalleer probleme voorkom, is die aksielyne vermanend, dreigend en selfs veroordelend. Waar geantisipeerde beproewing ter sprake is, is die aksielyne aanmoedigend en bemoedigend. Die oorhoofse probleem in genoemde gevalle is die probleem van identiteit en legitimiteit. Groepsgrense vervaag en sodoende bly identiteit in die slag. In hierdie verband is die verhouding met HHA, die leer en gepaardgaande werke, asook die geantisipeerde lyding vanweë die verbondenheid met HHA, belangrik.

\subsection{Die wyse van paradigmatiese toetsing}

Die doelwit met die paradigmatiese toetsing was om te kontroleer of die ter sprake intensie van die outeur ook blyk uit die res van die skrywe, naamlik situasie C (4:1-22:5) en D (22:6-21). Hierdie oefening was bloot 'n toetsing en 'n volledige analise is nie gedoen nie. Die ter sprake toetsing het die volgende behels. In die eerste plek is gevra of genoemde drie probleme ook in die res van die skrywe figureer. In hierdie verband is gelet op die akteurs en rolspelers wat die probleme veroorsaak. Tweedens is gelet op die aard van die aksielyne wat voorkom in die res van die skrywe. Uiteraard is die relasie tussen probleme en aksielyne ook vasgestel, naamlik korreleer dit. Hierdie ondersoek het op 'n geïntegreerde wyse geskied.

\section{VERHOUDINGS-, DWAALLEER-, EN GEANTISIPEERDE LYDINGSPROBLEME}

\subsection{Verhoudingsprobleme}

Verhoudingsprobleme tussen die kerk en HHA is uiteraard moeilik om na te speur. Motiewe, gedagtes en gesindhede is moeilik evalueerbaar. In situasie B was dit moontlik om die verhoudingsprobleme in die toepaslike kerke te definieer vanweë enkele faktore. Eerstens was HHA self aan die woord. Hy wat die vermoë het om die onsienlike te sien. Daarom kon aan Efese en Sardis gesê word dat daar verhoudingsprobleme is ten spyte van al die sigbare goeie werke wat oënskynlik op lewende verhoudings sou dui. Tweedens was HHA in konkrete situasies aan die woord en kon Hy op grond van konkrete werke vir Laodisea op die verhoudingsprobleem met Homself wys. In situasies $C(4: 1-22: 5)$ word egter met 'n wêreldwye en veralgemeende situasie gewerk. 'n Plaaslike kerk kom nie meer te sprake 
nie. HHA se rol verander in lyn hiermee van 'n kerkvisiteerder in konkrete situasies na die van ' $n$ transendentale ontvouer van God se raadsplan ${ }^{23}$. Die probleem rondom die verhouding van die kerke met HHA is in hierdie gedeelte dus moeilik analiseerbaar. Daar kan nogtans op die volgende gewys word.

* Aanbidding figureer in die ter sprake gedeeltes as 'n prominente saak $^{24}$. Op verskeie wyses word die hele kerk opgeroep om God alleen te aanbid en eer te gee. Die belangrikheid van 'n onversteurde verhouding word hiermee regdeur die skrywe beklemtoon. Die intieme, persoonlike en onversteurde verhouding wat in 21:1-22:5 geskets word, dui seer sekerlik ook op die belangrikheid van hierdie saak, al handel dit hier oor 'n eskatalogies prentjie. Die verbondsrelasie in terme van Vader en Seun word beklemtoon (21:7). Die waarskuwing dat diegene met 'n versteurde verhouding, of diegene wat nie in hierdie verhouding met God staan nie, uitgesluit word van gemeenskap met God, kom tweemaal voor $(21: 8,27)$. Hierdie saak word beklemtoon in die slot-situasie, situasie D (22:14-15).

* Die verskynsel van veralgemening beklemtoon ook hierdie saak. Vanaf 4:1 word slegs met twee groeperings gewerk, naamlik God se groep en die Satan se groep. Verhoudings is hier belangrik. God se groep bestaan uit mense wat gewas is deur die bloed van die Lam (4:9) en oorwin deur die bloed van die Lam (12:11). Hulle aanbid God en hulle name is reeds vanaf die skepping van die wêreld in die boek van die lewe, die boek van die Lam wat geslag is, geskrywe (13:8 en 17:8). Hierdie beskrywings druk gebeure uit wat 'n persoonlike verhouding impliseer.

\subsection{Dwaalleer en dwaalwerke: Afgodsdiens en onsedelikheid}

\subsubsection{Onsedelikheid}

\subsubsection{Analise insake die voorkoms van onsedelikheid}

In situasie B is gelet op konkrete onsedelike praktyke wat in verband met die leer van die Nikolaïete gebring word25. In 2:22 word onsedelikheid nader gepresiseer as owerspel en Isebel figureer prominent in hierdie verband ${ }^{26}$. Die aksielyne is uiteraard vermanend en dreigend. In die res van die skrywe word hierdie saak nagespoor deur te let op die voorkoms


en $\pi$ ó $\rho$ os. Die werkwoord is in situasie B gebruik om hierdie saak aan die orde te bring.

* Situasie C: In 9:21 word ook verwys na onsedelikheid, maar in die breër verband van wetteloosheid ${ }^{27}$. Die betrokkenes word aangedui as "die ander mense" (9:20). Onsedelikheid word hier nie nader omskryf nie 
en dit blyk dat Johannes hier besig is om te tipeer, naamlik dit is tipies van die kategorie mense wat die Satan aanbid ${ }^{28}$. Hier is geen aanduiding dat die kerk hieraan skuldig is nie. Die aksielyn is veroordelend ${ }^{29}$.

In hoofstuk 17 en 18 word sedeloosheid gepersonifiseer as 'n vrou (17:1). Sy het ook 'n naam en dit is Groot Babilon, die moeder van die sedeloses (17:5). Sy oefen heerskappy uit oor die konings van die aarde (17:18). Sy word ondersteun deur die Dier (17:3) en bestaan te midde van die mensdom (17:15). Die duiwels en bose geeste skuil by haar (18:2). Die sedelose vrou is ook verpersoonliking van welvaart, weelde en skittering, die dinge wat die lus van haar lewe was (18:14). Sedeloosheid verkry dus ook hier 'n breër betekenis, naamlik van 'n wêreldse ingesteldheid aangaande losbandigheid (17:6), wellus (18:7), ongeregtighede (18:5) en welvaart (18:3). Sedeloosheid verwys dus nie net na seksuele losbandigheid nie, maar beskryf eerder die inherente karakter van hierdie vrou. Sy is 'n verleidster, hetsy deur seksuele losbandigheid, hetsy deur welvaart, ensomeer. Haar doel is om die mensdom te verlei en die aarde te verwoes. Die konings se onsedelike verkeer met die sedelose vrou moet figuratief verstaan word $(18: 3,9)$. Hulle het gedeel in die sedelose dinge wat sy gebied het. Die sakemanne en skeepskapteins se verhouding met die vrou word nie as sedeloos beskryf nie. Hulle optrede vergelyk egter met die van die konings. Hulle het haar grenslose weelde gebruik om ryk te word $(18: 3,15,17,19)$.

Rome word dus gesien as die verpersoonliking en aanmoediger van sedeloosheid in die destydse wêreld ${ }^{30}$. Sedeloosheid in die breëre sin van hedonisme, soos reeds bespreek. Dit blyk verder dat die maghebbers die mag wat Rome verpersoonlik, misbruik het vir ander doeleindes, naamlik die aanbidding van die Dier (17:16-17). Die bedoeling aangaande die vrou se sedeloosheid (17:6) sou dan wees dat die maghebbers die onsedelikheid in die samelewing gebruik het om aanbidding van God af weg te keer. Woorde soos mislei (18:23) en verwoes (19:2) raak dan verstaanbaar.

* Situasie D: Die opmerking in 22:15 val in dieselfde kategorie as die van 9:2131.

\subsubsection{Opmerkings insake onsedelikheid as probleem}

Vir die huidige bespreking is dit nie van belang of onsedelikheid ' $n$ realiteit in die destydse samelewing was en of Rome hieraan skuldig was nie. Van belang is die persepsie van Johannes dat daar maghebbers en mense is wat los van God se wil lewe. Mense wat kwaad doen en dus die teenoorgestelde van wat reg is volgens God se wil ${ }^{32}$. Mense wat nie die gebooie van God nakom nie ${ }^{33}$. Mense wat sondes soos onsedelikheid, moord, diefstal, 
towery, losbandigheid en leuens doen. Hierdie dinge gebeur op so 'n groot skaal dat hy moet veralgemeen en tipeer in terme van twee groeperings van mense. Alle mense wat tot die Satan se groepering behoort, lewe onverskillig teenoor God se wil en laat hulle verlei deur hierdie wêreldse ingesteldheid. Hierdie hele verskynsel word versimboliseer deur die Sedelose Vrou, die moeder van die sedeloses. Die kragvolle, blatante en uitgebreide tekening van hierdie simbool beklemtoon dat sedeloosheid (wetteloosheid) ' $n$ prominente plek in Johannes se situasie-defmisie inneem. Sedeloosheid is 'n wesentlike probleem en gevaar vir die kerk. Dit neem ' $n$ groter plek as die van vervolging of verdrukking in. Daarom dat die cordeel wat in 17 tot 20 beskryf word, hierop konsentreer en dan wel in terme van " $\varepsilon \rho \gamma \alpha(20: 13)$. Waar die tradisioneel-aanvaarde vervolgers, die Draak en sy Diere ter sprake kom, geskied die oordeel as gevolg van hulle misleiding van die mensdom $(19: 20 ; 20: 3,8)$. Die doodmaak of vervolging van gelowiges is nie ter sprake nie, behalwe in die konteks van die sedelose vrou se aktiwiteite ${ }^{34}$. Sy veroorsaak die geestelike dood van gelowiges (17:6).

Die feit dat onsedelikheid getipeer word as die aktiwiteit van 'n bepaalde kategorie mense en verpersoonlik word deur die Vrou as 'n wêreldse ingesteldheid, laat blyk dat die probleem wat uitgespel word nie bloot handel oor morele kwessies nie, maar oor die gevare wat dit inhou vir die kerk se identiteit as die kerk hom nie daarvan distansieer nie. Dit handel hier oor groeperings en groepsgrense. Daarom is Johannes se aksielyn as gevolg van sy situasie-defmisie: "Gaan uit haar uit my volk sodat julle nie aan haar sondes deel kry nie..." (18:4) ${ }^{35}$. Hierdie aksielyn is belangrik. In die eerste plek impliseer die uitspraak dat HHA se volk nie buitekant staan of buite gevaar is nie, maar moet uitgaan. Laasgenoemde impliseer egter nie dat hulle geografiese afstand moet verkry nie, maar in terme van normes en gedrag wel 'n simboliese afstand. Tweedens is die aksielyn, omdat hulle nie afstand het nie, waarskuwend van aard. Die feit dat hierdie saak deurentyd voorkom en dat selfs twee hoofstukke aan hierdie saak afgestaan word, laat blyk dat onsedelikheid in die hele skrywe 'n wesentlike probleem is sover die kerk aangaan, nie slegs in hoofstuk 2-3 nie.

\subsubsection{Afgodsoffers}

Hierdie objek is naas, of saam met onsedelikheid die prominentste objek wat Johannes as ter sake indikeer regdeur Openbaring. 


\subsubsection{Analise insake die voorkoms van afgodery}

In situasie $B$ is gelet op die verwysing na die eet van afgodsoffervleis deur spesifieke gelowiges wat hulle daartoe laat verlei36. Johannes vergelyk die situasie met gebeure wat in Numeri 22 en verder opgeteken is. As gevolg van hierdie assosiasie van gebeure is dit duidelik dat die eet van afgodsoffervleis en afgodediens vir Johannes dieselfde saak is. Hy heg dus die betekenis van afgodery aan die objek "afgodsoffervleis". Hierdie saak word in die res van die skrywe nagespoor.

Situasie C: In 9:20 kom afgodery ter sprake. Hier word dit nader gepresiseer as die aanbidding van duiwels en handgemaakte gode. In hoofstuk 13 word afgodery in verband met die Dier en die Draak gebring. Afgodsdiens geskied deurdat 'n beeld van die Dier (:15), of die Dier self (:8), of die Draak (:4) aanbid word. Mense word verplig hiertoe (:16), asook doodgemaak indien hulle weier om te aanbid (:15). Mense word egter ook hiertoe verlei en mislei $(: 3-4,14)$. Johannes verwys uiteraard hier na 'n tydhistoriese verskynsel, naamlik die sogenaamde "keiserkultus". Die opmerkings in 9:20 impliseer dat Johannes egter ook afgodsdiens as 'n meer omvattende verskynsel beskou.

Die voorafgaande laat blyk dat afgodsdiens eintlik wentel om die saak van aanbidding. Afgodery is volgens Johannes dan ook die verskynsel dat "mense God nie aanbid en aan Hom die eer gee nie" (16:8). Daarom is dit selfs belangrik dat Johannes nie voor die voete van die engele mag neerval nie. Net God mag aanbid word (19:10). Soos in die geval van sedeloosheid, veralgemeen en tipeer Johannes ook wat die afgodsdiens aan betref. Die groepering van mense wat aan die Satan behoort, word omskryf as afgodsdienaars $(19: 20 ; 20: 4)$.

* Situasie D: Die gedagte dat die engele nie aanbid mag word nie, net God alleen, word hier in 22:8-9 beklemtoon. Hier word ook vermeld dat afgodsdienaars nie die nuwe Jerusalem kan binnegaan nie (22:15).

\subsubsection{Opmerkings insake afgodediens as probleem}

Die persepsie waarmee Johannes hier werk, is vir die doeleindes van hierdie studie belangrik. Dit blyk duidelik dat afgodsdiens prominent figureer as probleem in Johannes se situasie-defmisie. Die weer eens kragtige en blatante sketsing van die twee Diere simboliseer hierdie probleem en bedreiging vir die kerk. Hierteenoor staan die ewe indrukwekkende sketsing van God se troon, die wesens rondom die troon, asook die kragtige gebeure wat vanaf die troon uitgaan ${ }^{37}$. In beide hoofstukke 4 en 13 is aanbidding 'n sentrale tema. Die aard van die afgodsdiens beklemtoon ook die prominensie van die probleem. Johannes 
verwys in hierdie verband, byvoorbeeld in hoofstuk 13, na "die hele wêreld" (:3), "elke stam, volk, taal en nasie" (:7), en "al die bewoners van die aarde" (:8) wat die draak en die Dier aanbid en sal aanbid. Hy praat dus in terme van 'n wêreldwye situasie of verskynsel. Laastens word die prominensie van hierdie probleem ook beklemtoon deurdat die oordeel in 19-20 hoofsaaklik oor die Draak en die twee Diere handel.

Die kerk word regdeur Openbaring opgeroep om God te aanbid ${ }^{38}$, te volhard in hierdie aanbidding en te bly glo ${ }^{39}$. Anders gestel, om nie deel te neem aan afgodsdiens nie.

Samevattend: Dit is belangrik dat Johannes op verskeie plekke die Satan se groepering van mense in terme van onsedelikheid en afgodery definieer ${ }^{40}$. Die enigste ander tipering wat bygevoeg word, is die van dwaalleraars (22:15). In situasie B loop dwaalleer en afgodsdiens hand aan hand. Hierdie tipering is dus te wagte in die res van die skrywe. Die bespreking van onsedelikheid en afgodsdiens vestig hierdie verband ook op 'n ander wyse. Beide verskynsels geskied primêr (of veral) deur middel van misleiding. Die sedelose vrou ten opsigte van sedeloosheid en die Dier uit die aarde (die valse profeet) ten opsigte van afgodsdiens. Hiermee is dit duidelik dat die dwaalleerprobleem aangaande onsedelikheid en afgodsdiens regdeur Openbaring as probleem figureer wat aangespreek word.

\subsection{Geantisipeerde lyding vanweë die verbintenis met HHA: Vervol- ging en verdrukking}

Die boek Openbaring adem 'n gees van vervolging, verdrukking, oordeel en beproewing. Die verstaansraamwerk van die boek word dan ook in die algemeen gesien in terme van 'n situasie waar die kerk vervolg is deur die owerheid en/of die samelewing met gevolglike verdrukking of swaarkry vir die kerk. Heelwat objekte word in hierdie verband deur Johannes geïndikeer as ter sake. Ter wille van klariteit sou egter tussen 'n paar aanwendings van hierdie objekte onderskei moet word.

\subsubsection{Die uur van beproewing}

Hierdie objek wat in 3:11 voorkom, is simbool van "die tyd van posisionering" 41 . God is die aktant in hierdie gebeure wat oor die hele wêreld kom om die aardbewoners op die proef te stel en daardeur te posisioneer ten opsigte van Homself. Hierdie uur word beskryf deur die gebeure in 6:1-16:21. Genoemde gebeure word gekoppel aan die toorn van God wat die aardbewoners tref $(6: 16 ; 15: 1,7)$, onder andere met die oog op bekering $(9: 20 ; 16: 1 \mathrm{ev})^{42}$. Dit blyk met die oopmaak van die sewe seëls (6:1-8:2) dat hierdie tyd van beproewing ook die gelowige geld. Die 
versekering word egter gegee dat hulle staande sal bly $(6: 17 ; 7: 1 \mathrm{ev})$. Vanaf die vyfde trompet $(9: 4)$ in die reeks van sewe blyk die uur van posisionering slegs al die ongelowiges se lot te wees $(8: 6-11: 9)^{43}$. Die belangrike saak is dat die uur van beproewing ook die gelowiges betrek en dus nie deel uitmaak van een of ander vervolging van die kerk nie.

\subsubsection{Finale oordeel}

Die finale oordeel word hoofsaaklik vanaf 17:3-20:15 beskryf ${ }^{44}$, en dra by tot die "swaarkry"-gees in die boek, maar moet uiteraard daarvan onderskei word. God is ook in hierdie gebeure die aktant en die politieke en samelewingsopset is nie verantwoordelik vir hierdie gebeure nie. Die oordeelsgebeure raak ook nie die kerk nie.

\subsubsection{Verdrukking of vervolging van die kerk}

* Algemene voorkoms: Daar word meestal na die verdrukking of vervolging van die kerk (gelowiges) in die algemene sin van die woord verwys. Gelowiges in die algemeen en oor alle tye heen word vervolg, doodgewoon omdat hulle gelowiges is. In hierdie verband is die $\dot{\varepsilon} \nu$ 'I $\eta o o v$ frase (1:9) belangrik; omdat dit aandui dat die gelowige vanweë sy verbondenheid met Christus deel het aan swaarkry of verdrukking ${ }^{45}$. Hierdie gedagte word ook in die skrywe deur ander gedeeltes gesteun ${ }^{46}$. Johannes verwys in genoemde gedeeltes egter nie noodwendig na konkrete gebeure nie, maar veralgemeen.

Die verdrukking of vervolging van gelowiges word deur

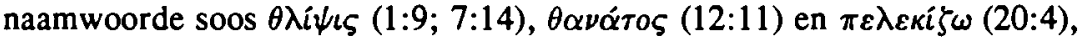

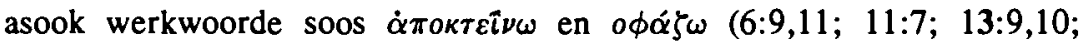
18:24) uitgedruk. In 16:6 (17:6) word na hierdie saak verwys deur middel van 'n hele beskrywing insake bloedvergieting. Die agente in hierdie vervolgingsverhaal wissel. Soms is dit die Draak (12:11), soms die Dier $(11: 7 ; 13: 9,10,15 ; 20: 4)$, of die aardbewoners $(16: 6 ; 17: 6 ; 18: 24 ; 6: 9$; 19:2) en soms word nie uitsluitsel gegee nie $(1: 9 ; 7: 14)$. Wat egter duidelik blyk, is dat ook in hierdie verband nie slegs verwys word na 'n bepaalde politieke opset nie. Die veralgemening en die verskeie agente maak so 'n simplistiese bepaling moeilik.

Dit is ook ' $n$ vraag of Johannes in sy verwysings 'n letterlike doodmaak of vervolging van gelowiges bedink, byvoorbeeld in die geval van 18:2447. Die vraag is verder of altyd na konkrete situasies en gevalle verwys word, of eerder na geantisipeerde situasies. Reddish maak in 'n artikel 'n paar opmerkings aangaande die aanwending van 'n martelaarsteologie in Openbaring ${ }^{48}$. Johannes werk volgens hom met 'n persepsie van 
verdrukking en gebruik 'n martelaars-simbool om vir die kerk aan te toon wat Christenskap moet behels, naamlik 'n kompromielose verbondenheid aan Christus. 'n Verbondenheid wat selfs nie deur die dood verbreek word nie.

Reddish is korrek dat Johannes met persepsies werk ${ }^{49}$. Dat die persepsie hoofsaaklik handel oor vervolging en verdrukking en dat dit dus die verstaansraamwerk van die boek bly, word betwyfel. Die situasiedefinisies toon aan dat die dominante aksielyne vermanend en nie bemoedigend is nie. Ten minste twee ander sake is belangrik in die boek, naamlik die eksklusiewe verhouding met Christus (teenpool is afgodsdiens) en sedeloosheid (dwaalleer en gepaardgaande werke). Johannes implementeer moontlik 'n martelaarsteologie. Die intensie van hierdie motief is egter anders. Die kerk word hiermee opgeroep om nie die geloof in Christus te kompromiteer met die geloof en praktyke van die samelewing nie.

- Konkrete gebruik: Die verwysing na die Antipas se dood (2:13) handel oor 'n gebeurtenis in die verlede en nie oor 'n heersende situasie nie. Die voorkoms van $\pi \dot{\alpha} \sigma \chi \omega, \pi \varepsilon \iota \rho \dot{\alpha} \zeta \omega$ en $\theta \lambda i \psi \iota \varsigma$ in Situasies B3 en 7 laat blyk dat die probleme wat Johannes hier aanspreek, handel oor situasies wat hy antisipeer. Die enigste moontlike verwysing na konkrete en temporêre vervolgingsgebeure word in hoofstuk 13 gevind waar daar moontlik ' $n$ simboliese verwysing is na heersende politieke en samelewingspraktyke. In hierdie geval is die Satan die agent deur middel van die gebruik van Rome en die keiserkultus. Die politieke opset en regering van die dag wek by Johannes die simbool van verdrukkers op. Dit handel hier oor 'n werktuig van die Satan wat aanbidders werf en gelowiges verdruk deur middel van verbanning, tronkstraf of doodstraf. Dat hierdie hoofstuk uitsluitlik 'n konkrete verdrukking-situasie impliseer, is egter nie noodwendig so nie. Johannes is vanaf 4:1 besig om visioene te sien en daar sou goedskiks geredeneer kon word dat hy sien wat nog moet gebeur. Hy skryf dan in hoofstuk 13 met die oog op geantisipeerde probleme.

Johannes mag ook besig wees om met 'n verdrukkingsmotief te werk wat hy in verskillende situasies op verskillende maniere aanwend. 'n Martelaarsteologie en martelaars-situasie moet dan onderskei word. Die een impliseer nie noodwendig die ander nie. Die een is ' $n$ verstaansraamwerk vir die skrywe en die ander 'n retoriese werktuig. Johannes sou ook met 'n verdrukkingstipering besig kon wees. Daarom dat "die Jode wat nie Jode is nie”, selfs wyer, naamlik al die bewoners van die aarde, ook verdrukkers is. Die wêreld is dus 'n verdrukkings-situasie vir die gelowige want uiteindelik sit die Satan agter alles en hy het nie ooghare vir die kerk nie (12:17). Binne die transendentale raamwerk van 12-13 handel 


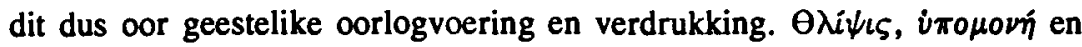
ander verdrukkingstiperings verkry dan 'n geestelik -simboliese betekenis.

Die voorafgaande laat blyk dat daar geen vaste gronde is om 'n konkrete verdrukking te postuleer as probleem wat deur die skrywe aangespreek word nie. Die ter sprake tekste kan in verskeie rigtings hanteer en verstaan word. Na aanleiding van die gegewens in hoofstuk 2-3 sou dus gekies moet word vir die saak van geantisipeerde lyding. Deur die visioene verkry Johannes 'n blik op wat aan die kom is. In terme van die komende lyding definieer hy 'n bepaalde probleem-situasie. Laasgenoemde is die probleem wat deur hom aangespreek word. Sy intensie in hierdie verband is dus tweërly van aard. Eerstens bemoedig hy die kerk met die feit dat alle gebeure en rolspelers in die hand van God is. Met die feit van God, wie God is, waartoe God instaat is, wat Hy reeds gedoen het en nog gaan doen, word die kerk verseker van haar veiligheid en toekoms insake die geantisipeerde lyding ${ }^{50}$. Tweedens word die kerk aangemoedig en opgeroep om te volhard en te bly glosi.

\subsection{Slotopmerkings}

Dit blyk dat Johannes in Situasie C en D (4:1-22:21) met dieselfde situasiedefinisie werk as in Situasie B (1:9-3:22). Johannes sien probleme rondom dwaalleer (onsedelikheid en afgodsdiens) en geantisipeerde lyding. Die verhouding met God is deurentyd van belang. Die aksielyne korreleer met die veronderstelde probleemsituasies.

Daar is egter 'n ontwikkeling in Situasie C en D in terme van rolspelers. Alhoewel die interaksie nog steeds tussen HHA en die kerk geskied, vervul Johannes 'n meer prominente rol. Johannes tree nie meer deur sy BA, naamlik HHA in interaksie met die kerk nie, maar deur middel van sy Self. Hy vertel wat hy sien en hoor. Sy BA vervul ook in hierdie gedeelte 'n ander rol met 'n ander simboliese waarde, soos reeds uitgewys. Die leraar se rol verval heeltemal en die kerk is teenwoordig as toeskouer. Die teenpartye (Satan en sy agente) en God en sy Seun vertoon meer prominent en hulle gedrag en interaksie word uitgebreid omskryf, geantispeer en ge-evalueer.

Die probleemsituasies en aksielyne verander dus nie. In Situasie $\mathbf{C}$ en $D$ word dit alles eerder meer sigbaar gemaak deurdat die sluiers van tyd en ruimte weggetrek word. Die kerk kan sien wat agter die skerms gebeur, hoe die Satan werksaam is, hoe groot die probleme is, wat die effek daarvan op die wêreld en gelowiges oor alle tye heen is, asook op watter skaal dit plaasvind. Hierdie sluiers wat weggetrek word, noodsaak die verandering in rolspelers, asook die toeskouerrol van die kerk. Die 
oorhoofse probleem behoort duidelik sigbaar te wees vir die aanskouende kerk: Identiteit! Wie hoort waar in hierdie skouspelagtige intrige tussen God en Satan? Waar is ons (die kerk) geposisioneer? Groepsgrense en die handhawing van groepsgrense deur middel van bepaalde gedrag, normes en waardes versterk identiteit. Identiteit help weer om duidelikheid te verkry aangaande waar die groepsgrense geleë is. Hierdie saak is die probleem wat aangespreek word in Openbaring.

\section{SLOTOPMERKINGS AANGAANDE DIE STUDIE}

\subsection{Die tradisionele verstaansraamwerk: Verdrukking}

Die situasie-definisies en aksielyne wat in Openbaring voorkom, toon duidelik aan dat die tradisionele verstaansraamwerk nie stand hou nie. Openbaring worstel nie met die probleem van verdrukking en lyding van die kerk nie. Openbaring worstel met verhoudings en dwaalleer (onsedelikheid, afgodsdiens) probleme in die kerk. Die koppeling in die skrywe van onsedelikheid en afgodery aan Rome, dui aan dat die meer resente gedagtes rondom die keiserkultus meriete het. Die keiserkultus het nie soseer gehandel oor "aanbid die keiser of sterf" nie. Hierdie kultus het eerder 'n religieuse sisteem verskaf wat sosiale sin en sekuriteit gegee het aan mense. Gelowiges kon dus spontaan verlei en mislei word tot normes en gedrag wat in stryd met God se wil is. Groepsgrense (identiteit) het sodoende vaag geword en is soms deurbreek, omdat normes en waardes onduidelik was.

\subsection{Die intensie van die outeur}

Die intensie van die outeur is nie om die kerk te bemoedig in 'n situasie van swaarkry nie. Die gevaar en probleme wat hy defmieer lei hom daartoe om te vermaan, te waarsku, op te roep tot bekering en selfs te dreig met optrede. Sy intensie is ook om die wat wel volhard in die regte weë aan te moedig en hulle te verseker van God se krag en beskikking in die swaar tye wat hy antisipeer oor hulle sal kom.

\subsection{Eksperimentering met simboiiese interaksionisme}

SI het geblyk 'n bruikbare perspektief te wees vir die eksplorasie van die intensie van die outeur. SI forseer die eksegeet om die betekenisse waarmee die teks werk na te spoor. SI maak dit ook moontlik om raak te sien watter simbole in interaksie met mekaar is, hoe 'n bepaalde situasie gekonstrueer is in terme van simbole en wat die gevolglike aksielyne is.

SI wys ook op die verskynsel dat, wat 'n bepaalde outeur definieer as die probleem in ' $n$ bepaalde situasie, nie noodwendig korreleer met wat 
historiese rekonstruksies aandui as problematies nie. In 'n tyd van geweldige kerkverdrukking is die verdrukking nie noodwendig ' $n$ of die probleem nie. 'n Outeur sou goedsmoeds ander probleme wat dieperliggend van aard is of selfs nog nie bestaan nie en na sy mening eerder aandag verdien, kon aanspreek. 'n Outeur sou ook doodgewoon met 'n ander persepsie aangaande gebeure kon werk. In beide gevalle sou die gebruik van 'n gerekonstrueerde historiese situasie as enigste verstaansraamwerk misleidend wees, soos in die geval van Openbaring gebeur het. SI leer dus dat betekenis en intensie geleë is in persepsies, dit wil sê in die interpretasie of defmisie van gebeure in bepaalde situasies.

SI, vanweë die bogenoemde eienskappe, maak dit moontlik om in Openbaring te onderskei tussen 'n martelaarsteologie (en retoriek) en 'n martelaar-situasie (historiese konteks). Hierdie onderskeiding is uiteraard belangrik vir die verstaan van 'n teks soos Openbaring. Die mag van retoriese transformasies, dit wil sê die skepping van alternatiewe simboliese universums mag nie oorskat word nie. Die objektiewe werklikheid en persepsies aangaande hierdie werklikheid, bly ' $n$ bepalende faktor in terme van oortuiging. Persepsies word nie bloot vervang of geruil nie.

Om mense wat in vervolging verkeer en werklik 'n krisis in hulle
realiteitskonstruksie beleef vanweë sodanige vervolging, aan te moedig en te
bemoedig deur middel van die retoriese skepping van alternatiewe
realiteitskonstruksies, is nie so eenvoudig nie. Die situasie, die werklikheid
verdwyn nie skielik nie. Hoekom sal die persepsie skielik verander? Om mense
wat nie werklik vervolg word nie op 'n geantisipeerde verdrukking-situasie te
trakteer en op grond van hierdie gefabriseerde situasie hulle te bemoedig met
alternatiewe simboliese universums, is selfs moeiliker ${ }^{52}$.

SI wys daarop dat Johannes eerder die simboliese universum van die kerk altereer. Hy skep nie iets wat nie bestaan nie. Hy ontbloot wat aan die gang is in die kerk en met die kerk. Vanuit hierdie sketsing, hierdie situasie-definisie, lei hy die kerk na die regstellings wat moet plaasvind.

\subsection{Kerklike taal}

Die nuwe insigte vanaf die sosiale wetenskappe veroorsaak dat die tradisionele verstaansraamwerk bloot in meer gesofistikeerde (sosiaal-wetenskaplike) en omvangrykende taal omskryf word ${ }^{53}$. In plaas van die historiese situasie, word nou gesoek na die sosio-historiese situasie. In plaas van verdrukking of vervolging as krisis, word nou gepraat van 'n krisis wat sosiaal, polities, ekonomies en godsdienstig van aard was. In plaas van bemoediging, bewerk die skrywe nou 'n transformasie van simboliese realiteite. 
In hierdie verband is dit belangrik om "terug te vertaal". SI het bepaalde konsepte en terminologie waarmee dit funksioneer. Hiermee is ook nie fout te vind nie. $\mathrm{Na}$ alles gedoen is, is dit egter belangrik om in bekende taal, die taal van die teologie en die kerk, te verduidelik wat bevind is. Sodoende is daar nie misleiding insake vordering van die verstaan van tekste nie.

\subsection{Tese}

Die situasie-definisie (geordende simbole) van Openbaring, asook die gekose aksielyne in die lig van die definiering van die situasie in Openbaring, getuig van sedelike verval en afgodsdiens (disintegrasie van groepsgrense), dit wil sê vermenging met die samelewing en hulle norme en waardes as probleem. Hierdie probleem hou in 'n groot mate verband met die toelating van dwaalleraars in die kerk. Die gevolg van die voorafgaande is dat die identiteit van die kerk vervaag het en die verhouding met (die aanbidding van) die Here in die slag gebly het. Die kerk beleef volgens sy eie persepsie nie soseer 'n krisis in hierdie verband nie. Johannes beleef wel 'n krisis met wat hy waarneem in die kerk, asook met wat hy antisipeer vir die kerk. Sy intensie is om sy krisis ook die kerk se krisis te maak en die kerk te bring by die nodige regstellings. Sy intensie is om die identiteit en groepsgrense van die kerk te herstel. In hierdie verband word bepaalde aksielyne voorgestel. Terug vertaal: Openbaring is geskryf om die kerk op te roep tot bekering. Die kerk mag nie deelneem aan afgodsdiens en ander sondige dade wat in stryd is met wat die Here wil nie. Sulke optrede lei tot afvalligheid en kerkverval. Dit speel ook in die hand van die Satan. Die kerk moet die Here aanbid deur te bly by die voorskrifte van die Woord. Die Waarheid (Woord), Skrifbeginsels, asook 'n heilige lewe is dus van wesenlike belang vir die kerk. Openbaring is ook geskryf om die kerk te wys op die lyding wat in die wêreld oor sy pad sal kom. Die kerk word aangemoedig om in sulke tye vas te hou aan die versekering wat God bied aangaande sy mag en beheer, sy oordeel wat nie sal uitbly nie, en die heerlikheid wat wag.

\section{NOTAS:}

1 Die oogmerk van hierdie artikel is om die konklusies van 'n proefskrif deur $\mathrm{H}$ Theunissen, Situasie-definisie en die Openbaring aan Johannes: 'n simboliesinteraksionistiese teksanalise, Universiteit van Pretoria 1997, weer te gee. Stellings wat in die artikel voorkom, is in die proefskrif gesubstansieer.

2 Vergelyk D L Barr, "Elephants and holograms: From metaphor to methodology in the study of John's Apocalypse", Society of Biblical Literature (1986 Seminar Papers), 403. 
3 Vergelyk die opmerkings van R H Smith, "Why John wrote the Apocalypse (Rev 1:9)", Currents in Theology and Mission 22/5 (1995), 356, asook van H-J Klauck, "Das Sendschreiben nach Pergamon und der Kaiserkult in der Johannesofferbarung", Biblica 73/2 (1992), 153.

4 J E Stanley, "Some words on the Bible's last word: An assessment of four resent commentaries on Revelation", Christian Scholars Review 22/3 (1993), bevestig in sy artikel dat hierdie sienswyse steeds prominent figureer. Hy evalueer vier resente kommentare op Openbaring (Boring, Fiorenza, Mulholland en Wall) en merk op dat "these authors posit a situation of persecution, actual or expected, as the occasion which motivated John to pen Revelation" (:291).

5 Vergelyk in hierdie verband Barr, $a w, 405-408$; P J J Botha, "God, emperor worship and society: Contemporary experiences and the book of Revelation", Neotestamentica 22/1 (1988), 87-102; H-J Klauck, a w, 154-155; F J Murphy, "The book of Revelation", Currents in Research: Biblical Studies 2 (1994), 187; Smith, $a w, 358$.

6 Vergelyk J G Gager, "Shall we marry our enemies? Sociology and the New Testament", Interpretation 36 (1982), 260.

7 Theunissen, $a w, 19-20$.

8 Theunissen, $a w, 20-21$.

9 Vergelyk R H Lauer \& W H Handel, The theory and application of simbolic interactionism, New York 21983.

10 Theunissen, $a w, 58 \mathrm{ev}$.

11 'n Situasie is 'n holistiese ruimte wat deur die akteur wat in interaksie tree (die Self) gekonstrueer word.

12 'n Objek en sy betekenis vorm 'n simbool.

13 'n Verwysingsgroep is die "eie groep", dit wil sê die groep waar die Self behoort en met wie hy normes en waardes deel (Theunissen, $a w, 43-46$ ). Hierdie groep word opgemaak deur een of meer BA's (Belangrike Andere of spesifieke indiwidue wat ' $n$ invloed uitoefen op die Self in terme van normes en waardes) en 'n VA (Veralgemeende Andere, 'n tegniese term in die sosiale sielkunde wat die totaliteit van indiwidue wat belangrik is vir die funksionering van die Self aandui).

14 Die postulate en konsepte waarmee situasie-defmisie opereer, is omvorm in 'n analitiese perspektief wat die aard van die studiebron, naamlik 'n Bybelse teks inagneem ( $\mathrm{Vgl}$ Theunissen, $a w, 67-72$ ).

15 Theunissen, $a w, 104-123$.

16 Vier makro-situasies is in Openbaring afgebaken (Vgl Theunissen, $a w, 125-$ 147), naamlik 1:1-8 (A), 1:9-3:22 (B), 4:1-22:5 (C) en 22:6-21 (D). Daar is aangetoon dat $B$ die konkrete situasie verteenwoordig en $C$ ' $n$ veralgemeende situasie (:131-134). B is in diepte ontleed en die bevindings is paradigmaties aan $\mathrm{C}$ getoets.

17 Ter wille van ruimte word aksielyne slegs aangedui as vermanend of bemoedigend. Vermanend verteenwoordig egter die aksielyne wat probleme in die kerk veronderstel naamlik, dreigend, veroordelend en waarskuwend. Bemoediging verteenwoordig die aksielyne wat positief is, dus ook aanmoediging.

18 Situasie B beslaan agt kleiner situasies, naamlik 1:9-20 wat as 'n inleidende situasie (B1) figureer, en dan B2-8 wat die briewe aan die sewe kerke bevat. 
Vergelyk Figuur 1.

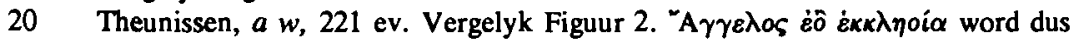
as een akteur, naamlik die "eie groep" hanteer.

21 Die teks skep in 1:11, 19 die indruk dat HHA by monde van Johannes funksioneer. Hierdie indruk word nie in 2:1-3:22 bevestig nie. Die opdrag om te skryf word regdeur die hele situasie $B$ herhaal. Hierdie verskynsel is analoog aan 'n situasie waar 'n pa sy seun opdrag gee om 'n boodskap oor te dra aan die ma. Die hele boodskap word egter ten aanhore van die ma gelewer. Dit is daarom belangrik om daarop te let dat 1:4 dit duidelik maak dat Johannes in interaksie is met die kerke. Hierdie interaksie neem in aanvang in 1:9 ( $\varepsilon^{\prime} \gamma \dot{\omega}$ 'I $\omega \dot{\alpha} \nu \nu \eta \varsigma)$. In hierdie interaksieproses gebruik Johannes sy BA ter wille van selfpresentasie, posisionering en legitimering.

22 Teenpartye verteenwoordig partye wat buite en teenoor die kerk staan.

23 Naas die inhoudelike dui die verandering in simboliese waarde van HHA dit ook aan. Hy word nou aangedui as die Leeu en die Lam wat geslag was (bv in 5:56), asook as die Woord van God (19:13).

24 Vergelyk die bespreking by 3.2.2.

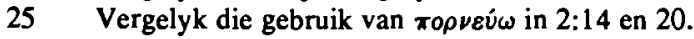

26 Vergelyk die gebruik van $\mu \circ \chi \chi \varepsilon v \omega$.

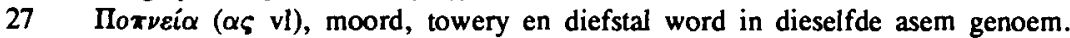
Vergelyk ook róp

28 Hierdie stelling word bevestig deur die opmerking in 9:4 en 14:1-5 in verband met die ander kategorie van mense, naamlik HHA se mense. Die tipiese van hierdie mense is dat hulle, hulle nie met vroumense besoedel het nie en kuis gebly het (14:4), asook dat hulle nie leuens vertel het nie (14:5).

29 Vergelyk die konteks, naamlik oordeel en plae, asook die verwysings na bekering in 9:20-21.

30 Hier word verwys na een of ander stad. In hierdie studie word die Domitiaanse datering voorveronderstel. Die omskrywing van die berge (17:19), asook ander gegewens, word dus beskou as aanduidings van Rome.

31 Vergelyk xóp $\nu$ os (ou ml).

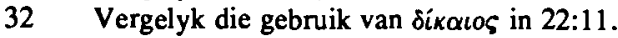

33 Vergelyk $\dot{\varepsilon} v o \lambda \dot{\eta}(\hat{\eta} \varsigma)$ in 12:17.

34 Klauck, $a w, 175$ wys daarop dat baie van die tekste in Openbaring wat verwys na "doodmaak", in besonder die tekste in 17-20, teen die agtergrond van die sterk "Literarisierung der Stoffe" bedink moet word. Hierby word aangevul deur te wys op die konteks van tekste soos 17:6 en 18:24. Dit handel hier oor die sedelose vrou. Die doodmaak van gelowiges verwys hier eerder na ' geestelike doodmaak vanweë misleiding en verleiding. Die enigste manier om die verwysing na profete en gelowiges dan te verstaan, is dat sulkes ook vanweë misleiding geestelik gesterf het. Dit sou impliseer dat die groot probleem wat Johannes aanspreek, is kerklike verval vanweè integrasie met die samelewing se sondige praktyke.

35 Vergelyk ook Klauck, $a w, 176$ in hierdie verband.

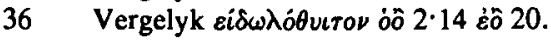

37 Vergelyk 4:1 ev.

38 Vergelyk die beskrywings in $4: 8-11 ; 5: 9-14 ; 7: 9-12 ; 15: 3-4$ en $19: 4-5$. Die regte gedrag vir die gelowige word as te ware gemodeleer. 
40 Vergelyk $9: 20-21 ; 14: 8-9 ; 16: 9,11 ; 21: 8$ en $22: 15$.

41 Vergelyk Theunissen, $a w, 413-415$.

42 Hierdie gedagte sou ansluit by die res van die Skrif wat vertel dat God die mens en skepping vervloek het as gevolg van die sondeval (Gen 3), en dat die gebrokenheid van hierdie bedeling (vloek van God en tegelykertyd gevolg van die sonde) voortduur tot en met die wederkoms wanneer alles nuut sal word (Rom 8; Op 21). Hierdie gebrokenheid bly sodat ongelowiges tot bekering kan kom (16:1 ev; 2 Pet 3:10) en gelowiges gelouter kan word (1 Pet 1; Heb 12:5 ev).

43 So ook ten opsigte van die sewe bakke (15-16).

44 Daar is proleptiese elemente van die oordeel in hoofstuk 6-16.

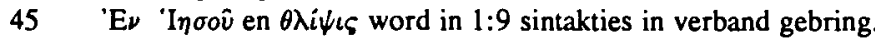

46 Vergelyk 6:9-11;12:11,17;13:9,10;16:6;17:6;18:24;20:4.

$47 \quad$ Vergelyk die opmerkings by nota 34 .

48 M G Reddish, "Martyr Christology in the Apocalypse", JSNT 33 (1988), 85-95 meen dat Johannes in ' $n$ situasie is waarin hy die persepsie het dat daar vervolging en verdrukking voorlê vir die kerk. Of dit die historiese situasie is, is nie ter sake nie. Die indruk wat hy skep is dat dit 'n tyd van krisis is. Hy meld verder dat 'n martelaars-Christologie deur die skrywer gebruik word om die gelowiges aan te moedig om getrou te bly in sodanige situasie (:90). Volgens hom is hierdie martelaarsgedagte die primêre motief van die skrywe (:86). Dit handel dus in die boek oor die konstruksie van 'n alternatiewe simboliese universum, want die ou orde (God is in beheer) het inmekaar gestort. Die draak en sy magte is die dominante kragte. 'n Ander verstaan van die realiteit was dus vir die lesers nodig $(: 92)$.

49 Vergelyk die voorafgaande opmerkings.

50 Openbaring verskaf hierdie sekerheid. Daar word begin by die troonvisioen in hoofstuk 4 en geeïndig met die nuwe Jerusalem, vry van die Draak, Diere, goddelose, sonde en hartseer.

51 Hierdie saak kom ook regdeur voor. Vergelyk egter 13:9-10.

52 Vergelyk Reddish, $a w, 86$. Vergelyk ook nota 48.

53 Vergelyk in hierdie verband die opmerkings van Richter in: S E Porter \& D Tombs (ed), Approaches to New Testament Study, Sheffield 1995, 270. 